\title{
Pengujian Efisiensi Pasar Dalam Merespon Pengumuman Kenaikan Harga Bahan Bakar Minyak Pada Perusahaan Papan Utama Bei
}

\author{
Vivi Ariyani \\ Fakultas Ekonomi, Prodi Manajemen-Unika Widya Mandala Madiun \\ Telp 081578762534, email: viviariyaniuwm@yahoo.com
}

\begin{abstract}
ABSTRAK
Tujuan dari penelitian ini adalah memberikan bukti empiris mengenai kandungan informasi pada peristiwa sebelum dan setelah pengumuman kenaikan harga bahan bakar minyak pada tanggal 17 November 2014. Dengan menggunakan sampel pada perusahaan yang terdaftar pada papan pengembangan di Bursa Efek Indonesia berjumlah 89 perusahaan, dengan periode jendela untuk data mingguan harga saham dilakukan delapan minggu sebelum $(h-8)$ dan delapan minggu sesudah $(h+8)$ dari tanggal pengumuman kenaikan bahan bakar minyak pada 17 November 2014. Hasil penelitian dengan mengggunakan paired sample test menjelaskan bahwa para investor tidak bereaksi secara berlebihan, hal ini dapat dijelakan dengan peristiwa pengumuman kenaikan harga bahan bakar minyak pada 17 November 2015 tidak memiliki kandungan informasi yang signifikan. Para investor melakukan tindakan wait dan see di bursa tidak menganggap peristiwa kenaikan bahan bakar minyak sebagai suatu peristiwa yang akan mempengaruhi harga saham dan indeks harga saham.
\end{abstract}

Kata kunci: event study, kenaikan BBM

\section{Pendahuluan}

Informasi yang diterima oleh investor di pasar modal dapat ditanggapi secara berbeda oleh investor. Dalam hal ini investor menyerap informasi yang diterima atau mengabaikannya. Efisiensi pasar di pasar modal dapat terlihat dari reaksi investor terhadap suatu informasi yang mereka terima dan memutuskan tindakan yang akan dilakukan. Menurut Hartono (2010) pengujian efisiensi pasar secara informasi bentuk setengah kuat adalah pengujian kandungan informasi yang melibatkan kecepatan reaksi dari pasar untuk menyerap informasi yang diumumkan. Investor dalam hal ini bereaksi dengan cepat untuk menyerap abnormal return untuk menuju harga keseimbangan yang baru. Penelitian ini berfokus pada pengujian efisiensi pasar yang ditinjau dari kecanggihan investor, dalam hal ini disebut efisiensi pasar setengah kuat secara keputusan. Pasar dikatakan efisien bentuk setengah kuat apabila tidak ada investor yang memperoleh abnormal return dari informasi yang diumumkan atau apabila memang ada abnormal return, maka pasar harus bereaksi dengan cepat untuk menyerap abnormal return (I Gede, dkk, 2015).

Pada penelitian efisiensi pasar ini informasi yang digunakan adalah kenaikan bahan bakar minyak yang resmi 


\section{JURNAL MANAJEMEN VOL. 5 NO. 2 DESEMBER 2015}

diumumkan oleh presiden Joko Widodo pada tanggal 17 November 2014 dan mulai diberlakukan pada tanggal 18 November 2014 pukul 00.00. Pengamat ekonomi dari Universitas Atmajaya (A Prasetyantoko dalam Ilyas, 2014) mengungkapkan ada dua alasan penting yang menjadikan pemerintah menaikkan harga BBM, yaitu pertama, volume subsidi BBM hanya dibatasi 46 juta kiloliter (kl) di tahun 2014, sehingga bila tidak dinaikkan maka akan e e u t , dan pemerintah melanggar Undang-undang (UU) APBN, namun perlu pengaturan distribusi hingga volume subsidi tersebut cukup hingga akhir tahun oleh pertamina. Kedua yang menyebabkan pemerintah harus menaikkan harga BBM bersubsidi adalah demi membangun kemandirian bangsa. Karena dari sisi ekonomi dalam jangka panjang kenaikan bahan bakar minyak adalah baik.

Kenaikan bahan bakar minyak yang diberlakukan oleh pemerintah bersamaan dengan turunnya harga minyak dunia. Reaksi investor terhadap kandungan informasi diukur dengan perubahan harga saham melalui abnormal return. Suatu pengumuman yang mempunyai kandungan informasi yang bernilai ekonomis akan memberikan abnormal return kepada pasar sebaliknya yang tidak memiliki kandungan informasi tidak memberikan abnormal return (Hartono: 2010). Beberapa penelitian mengenai efisiensi pasar memiliki kesimpulan yang berbeda, $\mathrm{Ni}$ ketut, dkk (2014) menemukan bahwa pengumuman harga bahan bakar minyak tahun 2013 tidak mempengaruhi reaksi investor baik sebelum ataupun sesudah tanggal pengumuman. Berbeda dengan Suarjana (2011) menemukan terdapat abnormal return yang signifikan pada periode $t-3$, $t-2$ dan $t+2$, yang artinya investor bereaksi cepat terhadap peristiwa penurunan harga bahan bakar minyak. Setiawan dan Hartono (2003); Marfuah (2006) menemukan bahwa investor di Indonesia tidak canggih dan masih native, sehingga tidak dapat bereaksi secara tepat. Suryawijaya (1998) menyatakan investor bereaksi negatif dan siknifikan dan secara spontan pada event date. Berdasarkan latar belakang yang diuraikan, penulis tertarik untuk mengajukan judul pengujian efisiensi pasar dalam merespon pengumuman kenaikan harga bahan bakar minyak Pada Perusahaan Papan Utama BEI 


\section{Kajian Pustaka dan Hipotesis}

\section{Efisiensi pasar}

Seorang investor yang akan berinvestasi di pasar modal akan mempertimbangkan return dan risiko yang akan diperoleh di masa yang akan datang. Dalam efisiensi pasar, investor menggunakan informasi dari pengumuman untuk mendapatkan return abnormal. Menurut Hanafi (2008) menyatakan bahwa investor tidak dapat memperoleh keuntungan abnormal yang konsisten. Apabila investor ingin memperoleh keuntungan abnormal yang konsisten maka investor harus menggunakan informasi yang belum tercermin dalam harga.

\section{Event Study}

Studi peristiwa (event study) merupakan studi yang mempelajari reaksi pasar terhadap suatu peristiwa yang informasinya dipublikasikan sebagai suatu pengumuman. Menurut Hartono (2010) event study dapat digunakan untuk menguji kandungan informasi dari suatu pengumuman. Pengujian yang akan dilakukan adalah pengujian kandungan informasi, guna melihat dan menjelaskan bahwa suatu informasi memiliki informasi yang dibutuhkan oleh investor dalam bereaksi dan mengambil suatu keputusan. Reaksi pasar ditunjukkan dengan adanya perubahan harga dari sekuritas perusahaan. Reaksi ini dapat diukur dengan mengunakan return sebagai nilai perubahan harga atau lebih dikenal dengan abnormal. Suatu pengumuman yang mempunyai kandungan informasi akan memberikan abnormal return kepada pasar.

\section{Indeks papan utama dan indeks papan} pengembangan

Indeks papan utama dan indeks papan pengembangan adalah indeks harga saham yang diharapkan dapat menggambarkan pergerakan indeks di masing-masing papa tersebut. Jumlah saham yang digunakan untuk perhitungan indeks adalah seluruh saham yang tercatat di masing-masing papan (kecuali beberapa saham yang berdasarkan pertimbangan tertentu tidak masuk dalam perhitungan seluruh indeks yang ada). Macam-macam pengumuman yang dapat mempengaruhi harga dari sekuritas (Hartono, 2010)

1. Pengumuman yang berhubungan dengan laba, seperti laporan tahunan awal, laporan tahunan detail, laporan interim awal, laporan interim detail, laporan perubahan metode-metode akuntansi, laporan auditor.

2. Pengumuman peramalan oleh pejabat perusahaan, seperti peramalan laba sebelum akhir tahun fiskal, estimasi 


\section{JURNAL MANAJEMEN VOL. 5 NO. 2 DESEMBER 2015}

laba setelah akhir tahun fiskal, peramalan penjualan

3. Pengumuman-pengumuman dividen, yang meliputi distribusi kas, distribusi saham.

4. Pengumuman-pengumuman pendanaaan, seperti pengumuman yang berhubungan dengan ekuitas, pengumuman yang berhubungan dengan hutang, pengumuman sekuritas hybrid, sewa guna, persetujuan standby credit, pelemparan saham kedua, pemecahan saham, pembelian saham kembali, pengumuman joint venture

5. Pengumuman-pengumuman yang berhubungan dengan pemerintah. Dampak dari peraturan baru, investegasi-investigasi terhadap kegiatan perusahaan, keputusan regulator

6. Pengumuman-pengumuman ketenagakerjaan. Negosiasi-negosiasi, kontrak-kontrak baru, pemogokan

7. Pengumuman-pengumuman investasi. Eksplorasi, usaha baru, ekspansi pabrik, penutupan pabrik, pengembangan $R \& D$

8. Pengumunan-pengumuman yang berhubungan dengan hukum. Tuntutan terhadap perusahaan atau terhadap manajernya, tuntutan oleh perusahaan atau oleh manajernya.
9. Pengumuman-pengumuman pemasaran-produksi-penjualan.

Pengiklanan, Rincian kontrak, produk baru, perubahan harga, penarikan produk, laporan-laporan produksi, laporan keamanan produk, laporanlaporan penjualan, rincian jaminan.

10. Pengumuma-pengumuman manajemen-direksi. Susunan direksi, manajemen, rincian struktur organisasi.

\section{Pengujian efisiensi terhadap pengumuman kenaikan bahan bakar minyak}

Pengujian pasar bentuk setengah kuat merupakan pengujian yang melibatkan kecepatan reaksi pasar untuk menyerap informasi yang diumumkan. Menurut Hartono (2010) pasar dikatakan efisien bentuk setengah kuat bila investor bereaksi dengan cepat untuk menyerap abnormal return untuk menuju ke harga keseimbangan yang baru. Apabila investor menyerap abnormal return dengan lambat, maka pasar dikatakan tidak efisien bentuk setengah kuat secara informasi.Sedangkan apabila tidak menimbulkan abnormal return artinya investor tidak bereaksi, karena reaksi investor terhadap informasi yang baru ditunukkan oleh abnormal return. Selain itu menurut Hanafi (2008) dalam pasar efisien bentuk setengah kuat 
ketika informasi dipublikasikan maka harga akan langsung berubah menyesuaikan informasi yang baru tersebut. Akan terdapat dua kemungkinan reaksi dari pengumuman, yang pertama yaitu pasar bereaksi secara berlebihan (overreaction). Maksudnya adalah bila ada berita baik, harga meningkat terlalu tinggi dari peningkatan yang seharusnya, kemudia akan stabil pada hari-hari berikutnya. Kedua terdapat kemungkinan reaksi pasar terjadi secara lambat. Penyesuaian tidak terjadi dengan cepat.

Informasi yang digunakan penulis dalam penelitian ini adalah pengumuman kenaikan harga bahan bakar minyak oleh pemerintah pada tanggal 17 November 2014, dalam hal ini harga bensin dan solar naik masing-masing sebesar Rp 2000 sehingga saat ini harga bensin menjadi Rp 8500 dan solar menjadi Rp 7500. penelitian terdahulu mengenai efisiensi pasar memiliki kesimpulan yang berbeda, Ni ketut, I made dan Nyoman Ari (2014) mengungkapkan bahwa pengumuman

\section{Metodologi}

Jenis penelitian yang digunakan dalam penelitian ini adalah studi peristiwa (event study). Jenis data yang digunakan adalah data sekunder, yaitu harga saham perusahaan yang termasuk ke dalam papan pengembangan. Harga saham yang harga bahan bakar minyak tahun 2013 tidak mempengaruhi reaksi investor baik sebelum ataupun sesudah tanggal pengumuman. Sedangkan Suarjana (2011) menemukan terdapat abnormal return yang signifikan pada periode $\mathrm{t}-3, \mathrm{t}-2$ dan $\mathrm{t}+2$, yang artinya investor bereaksi cepat terhadap peristiwa penurunan harga bahan bakar minyak. Setiawan dan Hartono (2003); Marfuah (2006) menemukan bahwa investor di Indonesia tidak canggih dan masih native, sehingga tidak dapat bereaksi secara tepat. Suryawijaya (1998) menyatakan investor bereaksi negatif dan siknifikan dan secara spontan pada event date.

Berdasarkan kajian teori dan penelitian terdahulu, hipotesis penelitian dirumuskan sebagai berikut :

$\mathrm{H}$ : Terdapat kandungan informasi pada peristiwa sebelum dan setelah pengumuman kenaikan harga bahan bakar minyak pada tanggal 17 November 2014

digunakan adalah harga saham mingguan selama periode jendela. Periode jendela data mingguan harga saham adalah delapan minggu sebelum (h-8) dan delapan minggu sesudah $(\mathrm{h}+8)$ dari tanggal pengumuman kenaikan bahan bakar minyak pada 17 November 2014. 


\section{JURNAL MANAJEMEN VOL. 5 NO. 2 DESEMBER 2015}

Gambar 3.1

Periode Peristiwa

$\begin{array}{lll}\mathrm{t}-10 & \mathrm{P} & \mathrm{t}+10\end{array}$

Populasi dalam penelitian ini, yaitu seluruh perusahaan yang termasuk ke dalam papan pengembangan di Bursa Efek Indonesia (BEI). Sampel pada penelitian ini adalah perusahaan di papan pengembangan Bursa Efek Indonesia yang memenuhi kriteria pengambilan sampel.

Reaksi pasar di ukur dengan melihat perbedaan abnormal return dan aktivitas volume perdagangan saham sebelum dan setelah pengumuman kenaikan harga bahan bakar minyak pada 17 November 2014. Harga saham dalam penelitian ini adalah harga saham harian perusahaan pada saat penutupan (Closing price).

Langkah-langkah yang dilakukan dalam penelitian ini adalah : (Hartono, 2010)

1. Menghitung Abnormal return

Abnormal return adalah selisih antara return sesungguhnya dengan return yang diharapkan.

$$
\text { RTNi.t }=\text { Ri.t }-E(R i . t)
$$

2. Return Realisasi

$$
E(\text { Ri. } t)=\frac{P t-P t}{P t-1}
$$

Keterangan :

Ri.t $=$ Return sesungguhnya pada saham i periode ke-t

$\mathrm{Pt}=$ Harga penutupan saham ke-i periode ke- $t$

Pt-1= Harga penutupan saham ke-i periode ke-t-1

3. Return Ekspektasi

Perhitungan return yang diharapkan menggunakan market adjusted model, yaitu yang menganggap bahwa return ekspektasi semua sekuritas di hari yang sama adalah sama dengan return indeks pasarnya.

4. Return rata-rata tidak normal (Average Abnormal Return)

$$
\text { RRTN }=\frac{\sum_{\mathbf{t}-1}^{\mathrm{k}} \text { RTNi. t }}{K}
$$

5. Pengujian statistik terhadap abnormal return

Pengujian abnormal return bertujuan untuk melihat return tidak normal yang ada di periode jendela. Nilai signifikan berarti abnormal return yang dimaksud secara statistik signifikan tidak sama 
dengan nol. Dalam hal ini berarti bernilai positif untuk kabar baik dan negatif untuk kabar buruk. Pengujian abnormal return secara keseluruhan dilakukan dengan mengujirat-rata abnormal return secara cross section untuk tiap periode jendela.

6. Menentukan tingkat signifikansi. Dalam penelitian ini menggunakan taraf nyata sebesar 5\% dengan derajat kebebasan n-1

7. Mengitung nilai t hitung

$$
t=R T N S i=\frac{\sum R T N S i t}{\sqrt{k}}
$$

Ket :

$\mathrm{t}=\mathrm{t}$ hitung untuk masing-

masing hari pada periode peristiwa
$\mathrm{RTNSi}=$ abnormal return portofolio pada periode peristiwa

RTNSit $=$ abnormal return sekuritas pada periode peristiwa

$\mathrm{K} \quad$ = jumlah sampel

8. Mengambil keputusan

Membandingkan nilai $t_{\text {hitung dengan }}$ $\mathrm{t}_{\text {tabel }}$ untuk mengambil keputusan dengan kriteria sebagai berikut:

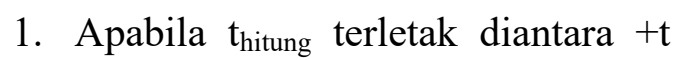
$\mathrm{a} / 2 ;(\mathrm{n}-1)$ dan $-\mathrm{t}$ a/2;(n1) maka Ho diterima

2. Apabila $t_{\text {hitung }}$ lebih kecil dari - $t$ $\mathrm{a} / 2 ;(\mathrm{n}-1)$ atau $\mathrm{t}_{\text {hitung }}$ lebih besar dari $+\mathrm{t} a / 2 ;(\mathrm{n}-1)$ maka Ho ditolak

\section{Hasil Uji Beda Abnormal Return Periode Sebelum dengan Sesudah Pengumuman Kenaikan Harga Bahan Bakar Minyak}

\begin{tabular}{|c|c|c|c|c|c|c|c|c|c|}
\hline \multicolumn{10}{|c|}{ Paired Samples Test } \\
\hline & & \multicolumn{5}{|c|}{ Paired Diff erences } & \multirow[b]{3}{*}{$\mathrm{t}$} & \multirow[b]{3}{*}{ df } & \multirow[b]{3}{*}{ Sig. (2-tailed) } \\
\hline & & \multirow[b]{2}{*}{ Mean } & \multirow[b]{2}{*}{ Std. Deviation } & \multirow{2}{*}{$\begin{array}{c}\text { Std. Error } \\
\text { Mean }\end{array}$} & \multicolumn{2}{|c|}{$\begin{array}{l}95 \% \text { Confidence } \\
\text { Interv al of the } \\
\text { Diff erence }\end{array}$} & & & \\
\hline & & & & & Lower & Upper & & & \\
\hline & $\begin{array}{l}\text { AAR_sebelum - } \\
\text { AAR_sesudah }\end{array}$ & 1.30028 & 3.45974 & 1.22320 & -1.59214 & 4.19269 & 1.063 & 7 & .323 \\
\hline
\end{tabular}

Pengamatan abnormal return periode sebelum dan sesudah pengumuman kenaikan harga bahan bakar minyak berdasarkan paired sample test pada tabel terlihat bahwa t-hitung abnormal return sebesar 1.063 dengan probabilitas 0.323 oleh karena $\mathrm{p}=0.323>0.05$, artinya tidak terdapat perbedaan abnormal return dengan hasil tidak signifikan pada periode sebelum dan setelah pengumuman kenaikan harga bahan bakar minyak. Dalam hal ini tidak terdapat kandungan informasi karena terjadi abnormal return namun tidak terdapat perbedaan yang signifikan. 


\section{JURNAL MANAJEMEN VOL. 5 NO. 2 DESEMBER 2015}

Hasil Uji t dan nilai probabilitas abnormal return selama periode peristiwa

\begin{tabular}{|c|c|c|}
\hline Uji-T & Sig & Keterangan \\
\hline Uji AR Gabungan & 0.323 & Tidak Signifikan \\
\hline AR-1 vs +1 & 0.091 & Tidak Signifikan \\
\hline AR-2 vs +2 & 0.957 & Tidak Signifikan \\
\hline AR-3 vs +3 & 0.182 & Tidak Signifikan \\
\hline AR -4 vs +4 & 0.380 & Tidak Signifikan \\
\hline AR -5 vs +5 & 0.406 & Tidak Signifikan \\
\hline AR -6 vs +6 & 0.373 & Tidak Signifikan \\
\hline AR -7 vs +7 & 0.352 & Tidak Signifikan \\
\hline AR -8 vs +8 & 0.247 & Tidak Signifikan \\
\hline
\end{tabular}

Pergerakan abnormal return yang terjadi selama periode peristiwa, dalam penelitian ini menggunakan Uji t dan nilai probabilitas menggunakan paired sample test pada tabel 4.2 Berdasarkan hasil pengujian signifikansi abnormal return ditemukan bahwa perubahan abnormal pada periode peristiwa tidak signifikan atau tidak terdapat kandungan informasi dari perubahan abnormal return. Suatu pengumuman yang memiliki kandungan informasi yang bernilai ekonomis akan memberikan abnormal return kepada pasar sebaliknya informasi yang tidak memiliki kandungan informasi tidak memberikan abnormal return (Hartono: 2010).

Hal ini memberikan penjelasan bahwa peristiwa pengumuman kenaikan harga bahan bakar minyak pada 17 November 2015 tidak memiliki kandungan informasi yang signifikan, sehingga para investor tidak bereaksi secara berlebihan. Para investor tidak menganggap peristiwa kenaikan bahan bakar minyak sebagai suatu peristiwa yang akan mempengaruhi harga saham dan indeks harga saham sehingga investor masih melakukan tindakan wait dan see di bursa. Sebelum tanggal 17 November 2015 terjadi upaya dari pemerintah untuk menghapus subsidi namun harga minyak dunia masih lebih tinggi dibandingkan harga domestik. Kenaikan harga bahan bakar adalah upaya pemerintah untuk mengalihkan subsidi dari sektor konsumtif menjadi produktif, khususnya infrastruktur, kesehatan dan pendidikan. Namun pemerintah menjelaskan bahwa perubahan kebijakan dilakukan dengan memperhatikan harga minyak dunia. Tindakan wait and see yang dilakukan oleh investor karena para investor tidak ingin mengambil risiko terlalu cepat dalam mengambil keputusan dari informasi eksternal perusahaan emiten. Hasil penelitian ini sejalan dengan penelitian I made dan Nyoman Ari, 2014; Ni ketut, dkk, 2014 yang menemukan bahwa pengumuman harga bahan bakar 
minyak tidak mempengaruhi reaksi investor baik sebelum ataupun sesudah tanggal pengumuman. Berbeda dengan hasil penelitian dari Suarjana (2011) menemukan abnormal return yang signifikan pada periode $\mathrm{t}-3, \mathrm{t}-2$ dan $\mathrm{t}+2$, yang artinya investor bereaksi cepat terhadap peristiwa penurunan harga bahan bakar minyak.

Landasan hukum pemerintah dalam menaikkan harga bahan bakar minyak (BBM) menurut Kementerian Energi dan Sumber Daya Mineral (ESDM) mengacu pada putusan Mahkamah Konstitusi (MK) dengan menerbitkan Peraturan Pemerintah Nomor 30 Tahun 2009 tentang Perubahan Peraturan Pemerintah Nomor 36 Tahun 2004 tentang Kegiatan Usaha Hilir Minyak dan Gas Bumi. PP tersebut mengubah Pasal 72 PP No 36/2004 menjadi berbunyi Harga bahan bakar minyak dan gas bumi diatur dan/atau ditetapkan oleh pemerintah. Alasan Mahkamah Konstitusi memutuskan hal ini karena diperlukan campur tangan pemerintah dalam kebijakan penentuan harga komoditas yang menguasai hajat hidup orang banyak, termasuk di dalamnya BBM dan gas bumi. Dengan dasar itu, pemerintah mengeluarkan Peraturan Presiden (Perpres) No.191/2014 tentang penyediaan, pendistribusian dan harga jual eceran BBM, diikuti Permen ESDM No.39/2014 dan Permen ESDM No.4/2014 tentang dikeluarkannya aturan BBM. Didalamnya dijelaskan bahwa ada 3 jenis BBM yang ditetapkan oleh pemerintah (Migasreview, 2014)

Kebijakan bahan bakar minyak oleh pemerintah dan harga minyak dunia yang berfluktuatif juga menjadikan investor berhati-hati dalam bertindak. Hal inilah yang menyebabkan pasar tidak bereaksi secara signifikan karena investor tidak ingin mengambil risiko atas investasi yang dilakukan. Pengamat Pasar Modal, Stefanus Mulyadi Handoko mengungkapkan bahwa investor lebih memilih aksi wait and see atau menunggu, sampai ada kepastian harga BBM subsidi (Tribunnews, 2014). Walaupun terjadi reaksi positif dari hasil safari Jokowi ke luar negeri, sempat membawa sedikit optimisme dengan mengalirnya dana asing kembali ke bursa dan sempat membawa saham konstruksi, semen dan sebagian saham perbankan untuk menguat, namun indeks saham tetap gagal naik akibat tekanan jual dari saham-saham sektor tambang dan energi, sebagai akibat menurunnya harga minyak dunia dan harga batubara. 


\section{JURNAL MANAJEMEN VOL. 5 NO. 2 DESEMBER 2015}

\section{Kesimpulan}

Berdasarkan analisis data dan pengujian statistik yang telah dilakukan, maka kesimpulan yang dapat diambil pada penelitian ini mengenai kandungan informasi pada peristiwa sebelum dan setelah pengumuman kenaikan harga bahan bakar minyak pada tanggal 17 November 2014, yaitu tidak terdapat kandungan informasi karena tidak mengakibatkan abnormal return yang signifikan pada saat periode peristiwa. Hal ini memberikan penjelasan bahwa peristiwa pengumuman kenaikan harga bahan bakar minyak pada 17 November 2015 tidak memiliki kandungan informasi yang signifikan, sehingga para investor tidak bereaksi secara berlebihan. Hal ini disebabkan investor menunggu sampai ada kepastian harga bahan bakar minyak bersubsidi. Selain itu pemerintah

\section{Daftar Pustaka}

Azhar M. . Jumat 28 November 2014. Opec Ogah kurangi Pasokan, Harga minyak Anjlok. Tempo

Cheng F. Lee, Gong Meng Chen and O ver M. Ru, 2001,"St c Return nd $\mathrm{V} t$ ty $\mathrm{n} C \mathrm{n}$ ' $\mathrm{s}$ St $\mathrm{c}$ Mret", T e J urn f Fnnce, Vol. 24, h 523-543.

Chordia, Tarun and Bhaskaran Swaminathan. 2000. Trading Volume and Cross-Autocorrelation in Stock Return. The Journal Finance.4(2), pp: 913-935.

Dini. 2014. Morgan Stanley: Reaksi Pasar Akan Positif Jika Harga BBM Naik berencana melakukan penundaan atau kenaikan bertahap karena harga minyak dunia yang cenderung turun. Sehingga para ivestor tidak menganggap peristiwa kenaikan bahan bakar minyak sebagai suatu peristiwa yang akan mempengaruhi harga saham dan indeks harga saham sehingga investor masih melakukan tindakan wait dan see di bursa.

Sedangkan berdasarkan hasil uji paired sample test tidak terdapat perbedaan abnormal return pada periode sebelum dan setelah pengumuman kenaikan harga bahan bakar minyak pada periode peristiwa. Hal ini menjelaskan bahwa tidak terdapat perbedaan sebelum dan setelah peristiwa pengumuman kenaikan harga bahan bakar minyak pada 17 November 2015 karena berdasarkan hasil $P$-value tidak terjadi perbedaan yang signifikan.

Saat ini. Kompas. Senin, 1 September 2014.

Fama, Eugene F. 1991. Efficient Capital Market II. Jurnal of Finance. Desember. 66(5), pp:1-21.

Hanafi, Mamduh. 2008. Manajemen Keuangan. Yogyakarta. BPFE

Hartono. 2010. Teori Portofolio dan Analisis Investasi. Edisi ketujuh. Yogyakarta.BPFE.

Ilyas Istianur Praditya.2014. Ini alasan kenapa harga bbm harus naik. Liputan6.com

Marfuah. 2006. Pengaruh Kecanggihan Investor Terhadap Ketepatan Reaksi Pasar Dalam Merespon 
Pengumunan Dividen Meningkat. JAAI Vol.10 No 2. Desember . Hal 137-154.

Ni ketut, I made dan NyomanAri. 2014. Analisis Reaksi Investor terhadap Kenaikan Harga Bahan Bakar Minyak di BEI. E-Journal S1 Ak Universitas Pendidikan Ganesha. Vol:2 No:1.

Setiawan Doddy dan Hartono Jogiyanto.2003. Pengujian Efisiensi PAsar Bentuk Setengah Kuat Secara Keputusan; Analisis Pengumuman Dividen Meningkat. Jurnal Riset Akuntansi Indonesia. Vol 6, No 2 Hal. 131-144.
Suarjana, I Wayan. 2011. Pengaruh Kebijakan Pemerintah Dalam Menurunkan Harga Bahan Bakar Minyak Terhadap Reaksi Pasar Saham di Bursa Efek Indonesia. Tesis Universitas Udayana

Suryawijaya.M A dan F A Setiawan (1998) Reaksi Pasar Modal Indonesia terhadap Peristiwa Politik Dalam Negeri, Event Study Pada Peristiwa 27 Juli 1996. Kelola No 18/VII/1998, h. 137-153

http://www.migasreview.com/post/143441 4394/pertamina-klaim-kenaikanharga-bbm-non-subsidi-sesuaiaturan.html

http://www.Tribunnews.com/alasanpemerintah-menaikan-bbm.html 